\title{
РІВЕНЬ ІНСУЛІНОПОДІБНОГО ФАКТОРА РОСТУ-1 ТА ГІДРОГЕН СУЛЬФІДУ В ЩУРІВ 3 НЕАЛКОГОЛЬНОЮ ЖИРОВОЮ ХВОРОБОЮ ПЕЧІНКИ, АСОЦІЙОВАНОЮ З ГІПЕРГОМОЦИСТЕЇНЕМІЄЮ
}

Вступ. Неалкогольна жирова хвороба печінки (НАЖХП) - хронічне захворювання, що об'єднує низку морфрологічних змін (стеатоз, стеатогепатит, стеатофріброз та цироз печінки). Розвиток НАЖХП часто супроводжується підвищенням рівня гомоцистеїну, з іншого боку - гіпергомоцистеїнемію (ГГЦ) вважають самостійним чинником стеатозу та фріброзу печінки. Важливу роль у регуляції фрункціонального стану печінки відіграють IGF-1 та газотрансмітер гідроген сульфрід ( $\left.\mathrm{H}_{2} \mathrm{~S}\right)$, але їх роль у патогенезі НАЖХП, асоційованої з ГГЦ, залишається невизначеною.

Мета дослідження - визначити рівень IGF-1 в сироватці крові та вміст $\mathrm{H}_{2}$ S у печінці щурів з НАЖXП, індукованою високожировою дієтою (ВЖД) та ї̈ поєднанням з тіолактоновою ГГЦ.

Методи дослідження. Досліди проведено на 56 білих щурах-самцях. Тварин було поділено на чотири групи: щури 1-ї і 2-ї груп отримували стандартну дієту, 3-ї і 4-ї - ВЖД упродовж 60 діб. Тваринам 2-ї і 4-ї груп щоденно вводили тіолактон гомоцистеїну (100 мг/ка внутрішньошлунково). Визначали рівень гомоцистеїну та IGF-1 в сироватці крові, а також вміст $\mathrm{H}_{2} \mathrm{~S}$ у печінці щурів.

Результати й обговорення. Застосування ВЖД, тіолактону гомоцистеїну й, особливо, їх поєднання викликало зниження рівня IGF-1 в сироватці крові та вмісту $\mathrm{H}_{2} \mathrm{~S}$ у печінці щурів. У тварин з НАЖХП, асоційованою з ГГЦ, вміст $\mathrm{H}_{2} \mathrm{~S}$ у печінці та рівень IGF-1 в крові були достовірно нижчими на 22,6 i 32,2 \%, ніж у щурів з ізольованою НАЖХП. Рівень гомоцистеїну обернено корелював з рівнем IGF-1 у крові та вмістом $\mathrm{H}_{2}$ S у печінці ( $\left.r=-0,68,-0,73, p<0,01\right)$. Десріцит антифріброзних медіаторів IGF-1 та $\mathrm{H}_{2} \mathrm{~S}$ може бути чинником прогресування НАЖХП, асоційованої з ГГЦ.

Висновок. 60-добове застосування ВЖД або тіолактону гомоцистеїну викликає зниження рівня IGF-1 в сироватці крові та вмісту $\mathrm{H}_{2} \mathrm{~S}$ у печінці, але найбільш суттєвий дефріцит цих медіаторів фрормується при поєднанні ВЖД з ГГЦ.

КЛЮЧОВІ СЛОВА: інсуліноподібний фактор росту-1; гідроген сульфід; гомоцистеїн; високожирова дієта; неалкогольна жирова хвороба печінки.

ВСТУП. Неалкогольна жирова хвороба печінки (НАЖХП) - хронічне захворювання, що об'єднує широкий спектр морорологічних змін (стеатоз, стеатогепатит, стеатофріброз, цироз печінки) тає вагомим чинником зростання смертності населення [1]. Розвиток НАЖХП часто супроводжується підвищенням рівня гомоцистеїну, з іншого боку - гіпергомоцистеїнемію (ГГЦ) вважають самостійним чинником стеатозу та фріброзу печінки [2-6]. Гіпергомоцистеїнемія $€$ досить розповсюдженим метаболічним розладом, в Україні її виявляють майже у 10 \% практично здорових дорослих осіб [7], а серед пацієнтів із хронічними захворюваннями печінки ( ) Д. О. Некрут, Н. В. Заічко, О. Б. Струтинська, 2017. частота ГГЦ може перевищувати 50 \% [5, 6]. Таким чином, дослідження патогенетичних особливостей НАЖХП, асоційованої з ГГЦ, залишається актуальним.

Важливу роль у регуляції фрункціонального стану печінки відіграє IGF-1, який контролює тканинний ріст, диференціацію та проліфрерацію гепатоцитів, ліпідний метаболізм, проявляє антиоксидантну і цитопротекторну дію, запобігає мітохондріальній диссрункції [8, 9]. Також у процесі обміну гомоцистеїну в печінці синтезується газотрансмітер гідроген сульфід $\left(\mathrm{H}_{2} \mathrm{~S}\right)$, який проявляє властивості антиоксиданта, цитопротектора, вазодилататора, бере участь у регуляції аутофрагії [10]. Було показано, що розвиток 
$\mathrm{CCl}_{4}$-індукованого фріброзу печінки супроводжується зниженням сироваткового та печінкового рівнів $\mathrm{H}_{2} \mathrm{~S}$ і пригніченням його ендогенного продукування [4, 11]. Проте роль IGF-1 та $\mathrm{H}_{2} \mathrm{~S}$ у патогенезі НАЖХП, асоційованої з ГГЦ, залишається невизначеною.

Мета дослідження - визначити рівень IGF-1 в сироватці крові та вміст $\mathrm{H}_{2} \mathrm{~S}$ у печінці щурів 3 НАЖХП, індукованою високожировою дієтою та іï поєднанням $з$ тіолактоновою ГГЦ.

МЕТОДИ ДОСЛІДЖЕННЯ. Досліди проведено на 56 білих лабораторних щурах-самцях із початковою масою 210-280 г. Під час експериментів тварини перебували в стандартних умовах віварію з 12-годинним світловим режимом день/ніч при температурі $(22 \pm 2)^{\circ} \mathrm{C}$ та відносній

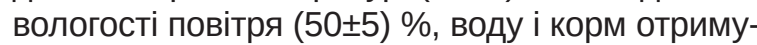
вали ad libitum згідно з нормативами. Усі досліди виконано відповідно до загальних етичних принципів експериментів на тваринах, ухвалених на Першому національному конгресі України 3 біоетики (Київ, 2001), положення Європейської конвенції про захист хребетних тварин, що використовуються для дослідних та інших наукових цілей (Страсбург, 1986), Директив Ради Європи 86/609/EЕC (1986), ЗаконуУкраїни від21.02.2006р. № 3447-IV "Про захист тварин від жорстокого поводження", що засвідчив комітет з біоетики Вінницького національного медичного університету імені М. І. Пирогова. У роботі застосовано модель НАЖХП, індукованої високожировою дієтою (ВЖД), яка поєднувалась із моделлю тіолактонової ГГЦ [12]. Тварин випадковим чином було поділено на чотири групи (n=14): щури 1-ї і 2-ї груп отримували стандартну дієту, збалансовану за всіма макро- та мікронутрієнтами, яка постачала 21 \% ккал за рахунок жирів і 62 \% ккал за рахунок вуглеводів, 3-ї і 4-ї - ВЖД, що постачала 54 \% ккал за рахунок жирів та $29 \%$ ккал за рахунок вуглеводів (частка протеїнів забезпечувала 17 \% ккал в обох дієтах). Тваринам 2-ї і 4-ї груп щоденно вводили тіолактон D,L-гомоцистеїну гідрохлорид (“Acros Organics”, Італія) В дозі 100 мг/кг внутрішньошлунково на $1 \%$ крохмальному гелі, щури груп порівняння отримували еквівалентну кількість розчинника. Тривалість досліду становила 60 діб, через 24 год після останнього введення речовин тварин піддавали евтаназії шляхом декапітації під тіопенталовим наркозом (тіопентал натрію 100 мг/кг внутрішньочеревно).

Сироватку крові отримували шляхом центрифугування цільної крові при 1500 об./хв 15 хв при $18-22{ }^{\circ} \mathrm{C}$. Аліквоти сироватки відбирали в мікропробірки Eppendorf і зберігали при $-20^{\circ} \mathrm{C}$ до проведення дослідження. Рівень IGF-1 та гомоцистеїну в сироватці крові визначали імуноферментним методом ELISA за допомогою наборів "Homocysteine EIA" (“Axis-Shield”, Англія) і "m/r IGF-1-ELISA (IGFBP-blocked)" ("Mediagnost", Німеччина) відповідно до інструкції фрірми-виробника на аналізаторі STAT FAX 303/PLUS ("Awareness Technologies", США).

Вміст $\mathrm{H}_{2} \mathrm{~S}$ у печінці визначали за методом [13]. Печінку персрузували холодним 1,15 \% розчином $\mathrm{KCl}$, наважку тканини гомогенізували протягом 1-2 хв в охолодженому середовищі 0,01 M NaOH у співвідношенні 1:5 (маса/об'єм) при 3000 об./хв (тефрлон-скло). Далі всі маніпуляції проводили в щільно закритих пластикових пробірках (для попередження втрат $\mathrm{H}_{2} \mathrm{~S}$ ). До 1 мл гомогенату додавали 250 мкл $50 \% \mathrm{CCl}_{3} \mathrm{COOH}$, центрифугували при 3000 об./хв 15 хв, відбирали супернатант. До 750 мл супернатанту додавали 150 мкл 20 мМ розчину N,N-диметил-парафренілендіаміну сульфрату в 7,2 М хлоридній кислоті, 150 мкл 30 мМ розчину $\mathrm{FeCl}_{3}$ в 1,2 М хлоридній кислоті, інкубували 20 хв при 20-22 ${ }^{\circ} \mathrm{C}$. Фотометрували при 670 нм.

Обробку первинного матеріалу проводили за допомогою універсальних статистичних програм MS Excel, SPSS Statistics 22 for Windows. Визначали середнє значення, стандартні помилки. Для оцінки відмінностей показників застосовували при нормальному розподілі параметричний t-критерій Стьюдента, при відхиленні від нормального розподілу - непараметричний U-критерій Манна-Уїтні, нормальність розподілу визначали за критерієм Шапіро-Уїлка. Зв'язок між показниками визначали за допомогою кореляційного аналізу за Пірсоном. Статистично значущими вважали відмінності при р<0,05. Результати наведено як $\mathrm{M} \pm \mathrm{m}$.

РЕЗУЛЬТАТИ Й ОБГОВОРЕННЯ. РеЗУЛЬТаТИ наших досліджень свідчать про те, що введення тіолактону гомоцистеїну на тлі стандартної дієти забезпечувало формування помірної ГГЦ, тоді як застосування ВЖД індукувало розвиток легкої ГГЦ (табл.).

Так, станом на 60-ту добу рівень гомоцистеїну в щурів 2-ї і 3-ї груп був вищим на 88,1 та 38,2 \%, ніж у тварин контрольної групи. Введення тіолактону гомоцистеїну на тлі ВЖД викликало найбільш виразну ГГЦ: рівень гомоцистеїну був достовірно вищим на 114,2 \%, ніж у контрольній групі, й на 13,9 та 55,0 \% вищим, ніж у щурів 2-ї і 3-ї груп (р<0,05).

Встановлено, що за умов ГГЦ, ВЖД і, особливо, при їх поєднанні суттєво знижувався рівень IGF-1 в сироватці крові щурів. Так, у тварин 1-ї групи рівень IGF-1 в сироватці крові коливався від 266,0 до 352,4 нг/мл (95 \% Cl) і в серед- 
Таблиця - Рівень гомоцистеїну й IGF-1 в сироватці крові щурів за високожирової дієти

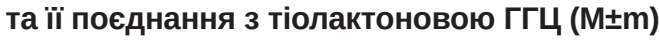

\begin{tabular}{|c|c|c|c|}
\hline \multicolumn{2}{|c|}{ Група щурів $(\mathrm{n}=14)$} & "ГОмоцистеїн, мкмоль/л & IGF-1, нг/Мл \\
\hline 1-ша & Контроль & $5,37 \pm 0,17$ & $303,4 \pm 7,91$ \\
\hline 2-га & ГГЦ & $10,1 \pm 0,32^{*}$ & $208,2 \pm 11,5^{*}$ \\
\hline 3-тя & ВЖД & $7,42 \pm 0,34^{\star * \#}$ & $255,9 \pm 9,87^{\star \#}$ \\
\hline 4-та & ВЖД+ГГЦ & $11,5 \pm 0,29$ *\#§ & $173,6 \pm 5,48^{\star \# \S}$ \\
\hline
\end{tabular}

Примітки:

1. * - достовірність відмінностей відносно 1-ї групи $(p<0,05)$.

2. \# - достовірність відмінностей відносно 2-ї групи $(p<0,05)$.

3. ${ }^{\S}$ - достовірність відмінностей відносно 3-ї групи $(p<0,05)$.

ньому становив 303,4 нг/мл. У щурів 2-ї і 3-ї груп сироватковий рівень IGF-1 був достовірно нижчим на 31,4 та 15,7 \%, ніж у тварин 1-ї групи. Зауважимо, що сироватковий рівень IGF-1 у щурів 4-ї групи виявився достовірно нижчим за такий у тварин 1-3 груп на 42,8; 16,6 та 32,2 \% відповідно.

3'ясовано, що застосування тіолактону гомоцистеїну та ВЖД забезпечувало формування помірного десріциту $\mathrm{H}_{2} \mathrm{~S}$ у печінці, який суттєво поглиблювався при поєднанні вказаних стеатогенних чинників (рис. 1).

Так, вміст $\mathrm{H}_{2} \mathrm{~S}$ у печінці щурів 1-ї групи коливався від 4,33 до 6,29 мкг/г тканини (95 \% Cl) і в середньому становив 5,09 мкг/г тканини. Водночас у печінці тварин 2-4 груп він був достовірно нижчим на 26,3; 21,0 та 38,9 \%, ніж у щурів 1-ї групи. Крім того, вміст $\mathrm{H}_{2} \mathrm{~S}$ у печінці тварин 4-ї групи був достовірно меншим на 17,1 та 22,6 \%, ніж у щурів 2-ї і 3-ї груп відповідно.

Кореляційний аналіз засвідчив (рис. 2) достовірний обернений зв'язок між рівнем гомоцистеїну та рівнем IGF-1 в сироватці крові $(r=-0,68, p<0,01)$. Також рівень гомоцистеїну сильно обернено корелював із вмістом $\mathrm{H}_{2} \mathrm{~S}$ y печінці ( $r=-0,73, p<0,01)$. Між сироватковим рівнем IGF-1 та вмістом $\mathrm{H}_{2} \mathrm{~S}$ у печінці виявили достовірний прямий зв'язок середньої сили $(r=0,48$, $\mathrm{p}<0,05)$.
Питання щодо молекулярних механізмів депримуючого впливу ГГЦ на систему IGF-1 потребує подальшого вивчення. Як відомо, близько 75 \% IGF-1, що циркулює в крові, секретується гепатоцитами [9]. Тому можна припустити, що зниження рівня IGF-1 в сироватці крові $€$ наслідком пригнічення його продукування в печінці щурів за умов ВЖД та ГГЦ.

Існують дані, що in vitro в культурі стовбурових клітин кісткового мозку високі рівні гомоцистеїну виявляли здатність індукувати оксидативний стрес та апоптоз і пригнічувати продукування IGF-1 [14]. За результатами клінічних спостережень, зростання рівня гомоцистеїну супроводжується зниженням рівня IGF-1 в сироватці крові практично здорових чоловіків [15] та осіб похилого віку [16]. 3 іншого боку, зменшення рівня IGF-1 може виявитись самостійним чинником, що індукує розвиток ГГЦ за НАЖХП, оскільки in vitro встановлено здатність цього ростового фрактора підвищувати активність метіонінсинтетази [17]. Зниження рівня IGF-1 в крові розглядають як чинник фрормування метаболічного синдрому, ожиріння та кардіоваскулярних ускладнень [9, 18].

Негативний вплив ГГЦ на обмін $\mathrm{H}_{2} \mathrm{~S}$ може реалізуватись через різні механізми, адже ензими метаболізму цієї біологічно активної молекули є редокс-чутливими протеїнами [19]. Також



Рис. 1. Вміст $\mathrm{H}_{2} \mathrm{~S}$ у печінці щурів за високожирової дієти та при їі поєднанні з тіолактоновою ГГЦ (* - р<0,05 відносно 1-ї групи; \# - р<0,05 відносно 2-ї групи 2; ${ }^{\S}-$ p<0,05 відносно 3-ї групи; $\mathrm{M} \pm m$ ). 

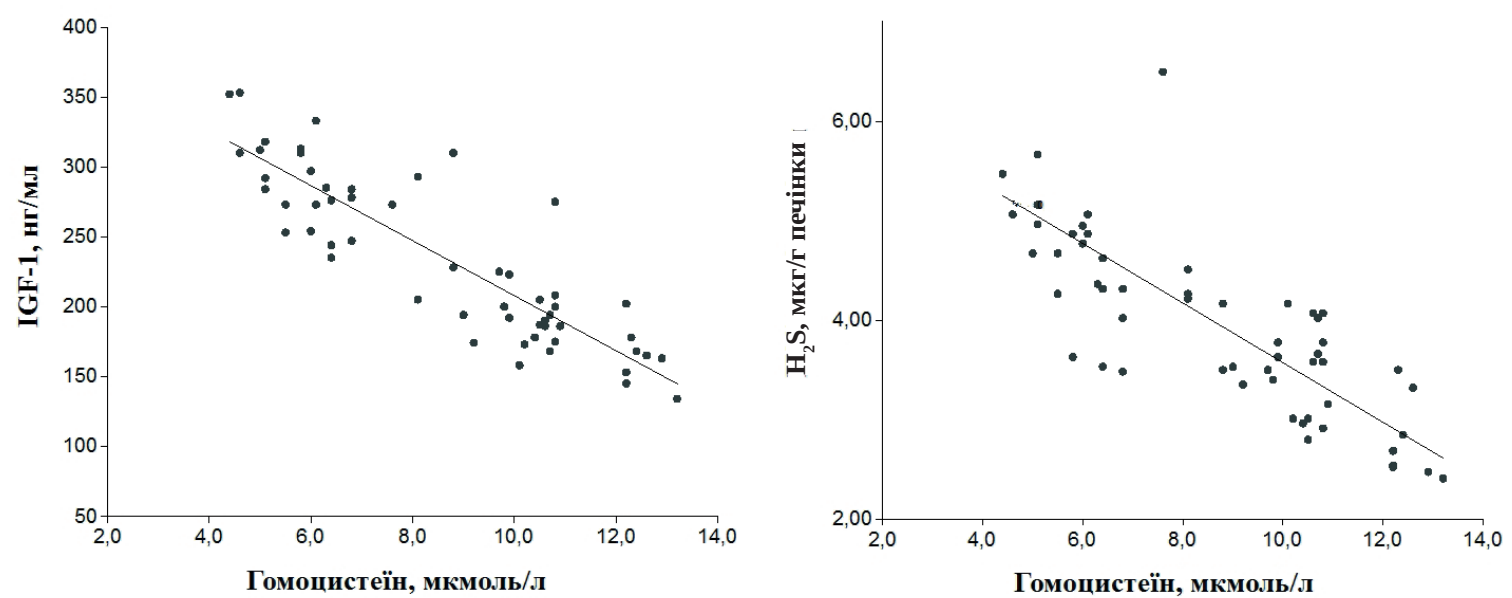

Рис. 2. Зв'язок рівня гомоцистеїну з рівнем IGF-1 в сироватці крові та вмістом $\mathrm{H}_{2}$ S у печінці щурів з НАЖXП і ГГЦ.

$\mathrm{H}_{2} \mathrm{~S}$ здатний взаємодіяти з активними формами кисню, реакційно-здатними ліпідними дериватами, тіоловими групами $[19,20]$. Раніше було показано, що при поєднанні ВЖД та ГГЦ істотно посилюється оксидативний стрес [12] і може прискорюватись споживання ендогенного $\mathrm{H}_{2} \mathrm{~S}$ y гепатоцитах. Існують дані, що донори $\mathrm{H}_{2} \mathrm{~S}$ проявляють антифіброзну активність: сприяють зниженню вмісту гіалуронової кислоти, гідроксипроліну, колагену, пригнічують проліфрерацію зірчастих клітин та апоптоз гепатоцитів у тварин з моделями печінкового фріброзу [11, 20]

Отже, зниження сироваткового рівня IGF-1 та вмісту $\mathrm{H}_{2} \mathrm{~S}$ у печінці може бути вагомим чинником прогресування НАЖХП, асоційованої 3 ГГЦ.

\section{СПИСОК ЛІТЕРАТУРИ}

1. The diagnosis and management of non-alcoholic fatty liver disease: Practice guideline by the American Association for the Study of Liver Diseases, American College of Gastroenterology, and the American Gastroenterological Association / N. Chalasani, Z. Younossi, J. E. Lavine [et al. ] // Am. J. Gastroenterol. -2012. - 107, № 6. - P. 811-826.

2. Cystathionine beta synthase deficiency promotes oxidative stress, fibrosis, and steatosis in mice liver K. Robert, J. Nehme, E. Bourdon [et al. ] // Gastroenterology. - 2005. - 128, № 5. - P. 1405-1415.

3. Association of homocysteine level with biopsyproven non-alcoholic fatty liver disease: a meta-analysis / Y. Dai, J. Zhu, D. Meng [et al.] // J. Clin. Biochem. Nutr. 2016. - 58, № 1. - P. 76-83.
ВИСНОВКИ. 60-добове застосування ВЖД або тіолактону гомоцистеїну викликає зниження рівня IGF-1 в сироватці крові та вмісту $\mathrm{H}_{2} \mathrm{~S}$ у печінці, але найбільш суттєвий десріцит цих медіаторів формується при поєднанні ВЖД 3 ГГЦ. У щурів з НАЖХП, асоційованою з ГГЦ, печінковий вміст $\mathrm{H}_{2} \mathrm{~S}$ та сироватковий рівень IGF-1 достовірно нижчі на 22,6 і 32,2 \%, ніж у тварин з ізольованою НАЖХП. Між рівнем гомоцистеїну в сироватці крові та рівнем IGF-1 в сироватці крові, а також вмістом $\mathrm{H}_{2} \mathrm{~S}$ у печінці існує достовірний обернений кореляційний зв'язок.

Перспективи подальших досліджень полягають у визначенні шляхів фрармакологічної корекції дефріциту вказаних антифріброзних медіаторів за умов НАЖХП.

4. Пентюк Н. О. Вплив гіпергомоцистеїнемії на формування CCl4-індукованого фріброзу печінки у щурів / Н. О. Пентюк // Сучасна гастроентерологія. 2009. - № 5 (49). - С. 33-37.

5. Пентюк Н. О. Метаболічні предиктори фріброзу печінки у хворих на хронічні гепатити / Н. О. Пентюк // Експерим. та клініч. медицина. - 2011. - № 1 (50). C. 134-138.

6. Глущенко С. В. Гипергомоцистеинемия как предиктор развития и прогрессирования неалкогольной жировой болезни печени / С. В. Глущенко // Пробл. безперервної медичної освіти та науки. - 2014. № 2. - С. 89-92.

7. Андрушко І. І. Рівні гомоцистеїну, цистеїну та аргініну у практично здорових осіб: вікові та статеві 
особливості / І. І. Андрушко // Укр. кардіол. журн. 2008. - № 5. - C. 89-95.

8. Inzaghi E. Insulin-like growth factors (IGF-I and -II): New actors in the development of non-alcoholic fatty liver disease [Електронний ресурс] / E. Inzaghi, S. Cianfarani, V. Nobili // Expert Review of Endocrinology \& Metabolism. - 2014. - Режим доступу до ресурcy: http://dx.doi.org/10. 1586/17446651.2014.900438

9. Insulin-like growth factor-1 deficiency and metabolic syndrome [Електронний ресурс] / G. A. Aguirre, J. Rodriguez De Ita, R. G. de la Garza, R. G. CastillaCortazar // J. Transl. Med. - 2016. - Режим доступу до pecypcy: https://translational-medicine.biomedcentral. com/articles/10.1186/s12967-015-0762-z

10. Hydrogen sulfide reduces serum triglyceride by activating liver autophagy via the AMPK-mTOR pathway / L. Sun, S. Zhang, C. Yu [et al. ] // Am. J. Physiol. Endocrinol. Metab. - 2015. - 309, № 11. - P. 11. doi: 10.1152/ ajpendo.00294.2015

11. Hydrogen sulfide attenuates carbon tetrachlorideinduced hepatotoxicity, liver cirrhosis and portal hypertension in rats [Електронний ресурc] / G. Tan, S. Pan, J. Li [et al.] // PLoS One. - 2011. - Режим доступу до ресурcy: http://dx.doi.org/10. 1371/journal. pone. 0025943.

12. Некрут Д. О. Вплив гіпергомоцистеїнемії на формування неалкогольної жирової хвороби печінки у щурів / Д. О. Некрут // Вісн. морфології. - 2016. -22, № 1. - С. $40-45$

13. Carvedilol induces endogenous hydrogen sulfide tissue concentration changes in various mouse organs / B. Wiliński, J. Wiliński, E. Somogyi [et al. ] // Folia Biol. (Krakow). - 2011. - 59, № 3-4. - P. 151-155.

14. Apoptosis of bone marrow mesenchymal stem cells caused by homocysteine via activating JNK signal
[Електронний ресурс] / В. Cai, X. Li, Y. Wang [et al.] // PLoS One. - 2013. - Режим доступу до ресурсу: http:// dx.doi.org/10.1371/journal. pone. 0063561.

15. A panel study on the effects of a Chinese medicinal suppository, Vigconic VI-28, on insulin-like growth factor 1 and homocysteine in healthy men / S. H. Chui, K. Chan, R. N. Wong, K. J. Chen // Methods Find Exp. Clin. Pharmacol. - 2004. - 26, № 5. - P. 349-355.

16. The effects of long-term resistance exercise on the relationship between neurocognitive performance and GH, IGF-1, and homocysteine levels in the elderly [Електронний ресурс] / C. L. Tsai, C. H. Wang, C. Y. Pan, F. C. Chen // Front Behav Neurosci. - 2015. - Режим доступу до ресурсу: https://doi.org/10 3389/fnbeh.2015.00023.

17. Activation of methionine synthase by insulin-like growth factor-1 and dopamine: a target for neurodevelopmental toxins and thimerosa / M. Waly, H. Olteanu, R. Banerjee [et al.] // Mol. Psychiatry. - 2004. - 9, № 4. P. 358-370.

18. Ren J. The insulin-like growth factor I system: physiological and pathophysiological implication in cardiovascular diseases associated with metabolic syndrome / J. Ren, P. Anversa // Biochem. Pharmacol. 2015. - 93, № 4. - P. 409-417.

19. Hydrogen sulfide: modern aspects of metabolism, biological and medical role / N. V. Zaichko, A. V. Melnik, M. M. Yoltukhivskyy [et al. ] // Ukr. Biochem. J. - 2014. 86, № 5. - P. 5-25.

20. Hydrogen sulfide as a potential therapeutic target in fibrosis [Електронний ресурc] / S. Zhang, C. Pan, F. Zhou [et al.] // Oxid. Med. Cell Longev. - 2015. - Режим доступудо ресурсу: http://dx.doi.org/10.1155/2015/593407.

\section{REFERENCES}

1. Chalasani, N., Younossi, Z., Lavine, J.E., Diehl, A.M., Brunt, E.M., Cusi, K., ... Sanyal, A.J. (2012). The diagnosis and management of non-alcoholic fatty liver disease: Practice guideline by the American Association for the Study of Liver Diseases, American College of Gastroenterology, and the American Gastroenterological Association. Am. J. Gastroenterol., 107 (6), 811-826.

2. Robert, K., Nehme, J., Bourdon, E., Pivert, G., Friguet, B., Delcayre, C., ... Janel, N. (2005). Cystathionine beta synthase deficiency promotes oxidative stress, fibrosis, and steatosis in mice liver. Gastroenterology, 128 (5), 1405-1415.

3. Dai, Y., Zhu, J., Meng, D., Yu, C., \& Li, Y. (2016). Association of homocysteine level with biopsy-proven non-alcoholic fatty liver disease: a meta-analysis. J. Clin. Biochem. Nutr., 58 (1), 76-83.
4. Pentiuk, N.O. (2009). Vplyv hiperhomotsysteinemii na formuvannia $\mathrm{CCl}_{4}$-indukovanoho fibrozu pechinky u shchuriv [The influence of hyperhomocysteinemia on formation $\mathrm{CCl}_{4}$-induced liver fibrosis in rats]. Suchasna hastroenterolohiia - Modern Gastroenterology, 49 (5), 33-37 [in Ukrainian].

5. Pentiuk, N.O. (2011). Metabolichni predyktory fibrozu pechinky u khvorykh na khronichni hepatyty [Metabolic predictors of liver fibrosis in patients with chronic hepatitis]. Eksperymentalna ta klinichna medytsyna - Experimental and Clinical Medicine, 50 (1), 134138 [in Ukrainian].

6. Hlushchenko, S.V. (2014). Gipergomotsysteinemiya kak prediktor razvitiya i progressirovaniya nealkogolnoyi zhirovoyi bolezni pecheni [Hyperhomocysteinemia as a predictor of the development and progressing of nonalcoholic fatty liver disease]. Problemy bezperervnoi 
medychnoi osvity ta nauky - Problems of Continuous Medical Education and Science, 2, 89-92 [in Russian].

7. Andrushko, I.I. (2008). Rivni homotsysteinu, tsysteinu ta arhininu u praktychno zdorovykh osib: vikovi ta statevi osoblyvosti [Levels of homocysteine, cysteine and arginine in healthy individuals: age and sexual peculiarities]. Ukrainskyi kardiolohichnyi zhurnal - Ukrainian Journal of Cardiology, 5, 89-95 [in Ukrainian].

8. Inzaghi, E., Cianfarani, S., Nobili, V. (2014). Insulin-like growth factors (IGF-I and -II): New actors in the development of non-alcoholic fatty liver disease. Expert Review of Endocrinology \& Metabolism. Retrieved from: http://dx.doi.org/10.586/17446651.2014.900438

9. Aguirre, G.A., Rodriguez, De Ita J., Garza, de la R. G., Castilla-Cortazar, R. G. (2016). Insulin-like growth factor-1 deficiency and metabolic syndrome. Journal of Translational Medicine. Retrieved from: https://translational-medicine.biomedcentral.com/articles/10.1186/ s12967-015-0762-z .

10. Sun, L., Zhang, S., Yu, C., Pan, Z., Liu, Y., Zhao, J., ... Li, Y. (2015). Hydrogen sulfide reduces serum triglyceride by activating liver autophagy via the AMPKmTOR pathway. Am. J. Physiol. Endocrinol. Metab., 309 (11), 11. doi: 10.1152/ajpendo.00294.2015.

11. Tan, G., Pan, S., Li, J., Dong, X., Kang, K., Zhao, M., ... Sun, X. (2011). Hydrogen sulfide attenuates carbon tetrachloride-induced hepatotoxicity, liver cirrhosis and portal hypertension in rats. PLoS One. Retrieved from: http://dx.doi.org/10.1371/journal.pone.0025943.

12. Nekrut, D.O. (2016). Vplyv hiperhomotsysteinemii na formuvannia nealkoholnoi zhyrovoi khvoroby pechinky u shchuriv [Influence of hyperhomocysteinemia on nonalcoholic fatty liver disease formation in rats]. Visnyk morfolohii - Reports of Morphology, 22 (1), 40-45 [in Ukrainian].

13. Wilinski, B., Wilinski, J., Somogyi, E., Piotrowska, J., Goralska, M., \& Macura, B. (2011). Carvedilol in- duces endogenous hydrogen sulfide tissue concentration changes in various mouse organs. Folia Biol. (Krakow), 59 (3-4), 151-155.

14. Cai, B., Li, X., Wang, Y., Liu, Y., Yang, F., Chen, H., ... Lu, Y. (2013). Apoptosis of bone marrow mesenchymal stem cells caused by homocysteine via activating JNK signal. PLoS One. Retrieved from: http://dx.doi. org/10.1371/journal.pone.0063561.

15. Chui, S.H., Chan, K., Wong, R.N., \& Chen, K.J. (2004). A panel study on the effects of a Chinese medicinal suppository, Vigconic VI-28, on insulin-like growth factor 1 and homocysteine in healthy men. Methods Find Exp. Clin. Pharmacol., 26 (5), 349-355.

16. Tsai, C.L., Wang, C.H., Pan, C.Y., \& Chen, F.C. (2015). The effects of long-term resistance exercise on the relationship between neurocognitive performance and GH, IGF-1, and homocysteine levels in the elderly. Front Behav. Neurosci. Retrieved from: https://doi. org/10.3389/fnbeh.2015.00023.

17. Waly, M., Olteanu, H., Banerjee, R., Choi, S.W., Mason, J.B., Parker, B.S., ... Deth, R.C. (2004). Activation of methionine synthase by insulin-like growth factor-1 and dopamine: a target for neurodevelopmental toxins and thimerosa. Mol. Psychiatry., 9 (4), 358-370.

18. Ren, J., \& Anversa, P. (2015). The insulin-like growth factor I system: physiological and pathophysiological implication in cardiovascular diseases associated with metabolic syndrome. Biochem. Pharmacol., 93 (4), 409-417.

19. Zaichko, N.V., Melnik, A.V., Yoltukhivskyy, M.M., Olhovskiy, A.S., \& Palamarchuk, I.V. (2014). Hydrogen sulfide: modern aspects of metabolism, biological and medical role. Ukr. Biochem. J., 86 (5), 5-25.

20. Zhang, S., Pan, C., Zhou, F., Yuan, Z., Wang, H., Cui, W., \& Zhang, G. (2015). Hydrogen sulfide as a potential therapeutic target in fibrosis. Oxidative Medicine and Cellular Longevity. Retrieved from: http://dx.doi. org/10.1155/2015/593407.

Д. А. Некрут, Н. В. Заичко, Е. Б. Струтинская ВИННИЦКИЙ НАЦИОНАЛЬНЫЙ МЕДИЦИНСКИЙ УНИВЕРСИТЕТ ИМЕНИ Н. И. ПИРОГОВА

\section{УРОВЕНЬ ИНСУЛИНОПОДОБНОГО ФАКТОРА РОСТА-1 И СЕРОВОДОРОДА У КРЫС С НЕАЛКОГОЛЬНОЙ ЖИРОВОЙ БОЛЕЗНЬЮ ПЕЧЕНИ, АССОЦИИРОВАННОЙ С ГИПЕРГОМОЦИСТЕИНЕМИЕЙ}

\section{Резюме}

Вступление. Неалкогольная жировая болезнь печени (НАЖБП) - хроническое заболевание, что объединяет ряд морфологических изменений (стеатогепатит, стеатофиброз и цирроз печени). Развитие НАЖБП часто сопровождается повышением уровня гомоцистеина, с другой стороны - гипергомоцистеинемию (ГГЦ) считают самостоятельным фрактором стеатоза и фриброза печени. Важную роль в регуляции фрункционального состояния печени играют IGF-1 и газотрансмиттер сероводород ( $\left.\mathrm{H}_{2} \mathrm{~S}\right), \mathrm{Ho}$ их роль в патогенезе НАЖБП, ассоциированной с ГГЦ, остается неясной. 
Цель исследования - определить уровень IGF-1 в сыворотке крови и содержание $\mathrm{H}_{2} \mathrm{~S}$ в печени крыс с НАЖБП, индуцированной высокожировой диетой (ВЖД) и ее сочетанием с тиолактоновой ГГЦ.

Методы исследования. Опыты проведены на 56 белых крысах-самцах. Животные были разделены на четыре группы: крысы 1-й и 2-й групп получали стандартную диету, 3-й и 4-й - ВЖД в течение 60 суток. Животным 2-й и 4-й групп ежедневно вводили тиолактон гомоцистеина (100 мг/кг внутрижелудочно). Определяли уровень гомоцистеина и IGF-1 в сыворотке крови, а также содержание $\mathrm{H}_{2} \mathrm{~S}$ в печени крыс.

Результаты и обсуждение. Применение ВЖД, тиолактона гомоцистеина и, особенно, их сочетания вызывало снижение уровня IGF-1 в сыворотке крови и содержания $\mathrm{H}_{2} \mathrm{~S}$ в печени крыс. Уживотных с НАЖБП, ассоциированной с ГГЦ, содержание $\mathrm{H}_{2} \mathrm{~S}$ в печени и уровень IGF-1 в крови были достоверно ниже на 22,6 и 32,2 \%, чем у крыс с изолированной НАЖБП. Уровень гомоцистеина обратно коррелировал с уровнем IGF-1 в крови и содержанием $\mathrm{H}_{2} \mathrm{~S}$ в печени ( $\left.r=-0,68,-0,73, p<0,01\right)$. Дефицит антифриброзных медиаторов IGF-1 и $\mathrm{H}_{2} \mathrm{~S}$ может быть фрактором прогрессирования НАЖБП, ассоциированной с ГГи.

Вывод. 60-суточное применение ВЖД или тиолактона гомоцистеина вызывает снижение уровня IGF-1 в сыворотке крови и содержания $\mathrm{H}_{2} \mathrm{~S}$ в печени, но наиболее существенный дефицит этих медиаторов фрормируется при сочетании ВЖД с ГГц.

КЛЮЧЕВЫЕ СЛОВА: инсулиноподобный фрактор роста-1; сероводород; гомоцистеин; высокожировая диета; неалкогольная жировая болезнь печени.

D. O. Nekrut, N. V. Zaichko, O. B. Strutinska

M. PYROHOV VINNYTSIA NATIONAL MEDICAL UNIVERSITY

\section{LEVELS OF INSULIN-LIKE GROWTH FACTOR-1 AND HYDROGEN SULFIDE IN RATS WITH NONALCOHOLIC FATTY LIVER DISEASE ASSOCIATED WITH HYPERHOMOCYSTEINEMIA}

\section{Summary}

Introduction. Evolution of nonalcoholic fatty liver disease (NAFLD) is often accompanied by increased levels of homocysteine, on the other hand hyperhomocysteinemia (HHC) is considered as an independent factor for steatosis and fibrosis of the liver. An important role in regulating of liver functional state has IGF-1 and gas mediator - hydrogen sulfide $\left(\mathrm{H}_{2} \mathrm{~S}\right)$, but their role in the pathogenesis NAFLD associated with HHC, is not certain.

The aim of the study - to investigate level of insulin-like growth factor-1 (IGF-1) in blood and concentration of $\mathrm{H}_{2} \mathrm{~S}$ in the liver of rats with NAFLD induced by high fat diet (HFD) and its combination with HHC.

Methods of the research. The experiment was performed on 56 white male rats. Animals were divided into 4 groups. Group 1 and group 2 received standard diet, group 3 and group 4 received HFD for 60 days. Rats from groups 2 and 4 were injected intragastrically daily by thiolakton homocysteine in the dose of $100 \mathrm{mg} / \mathrm{kg}$. After experiment the levels of homocysteine and IGF-1 in serum and $\mathrm{H}_{2} \mathrm{~S}$ content in the liver of rats were determined.

Results and Discussion. Homocysteine thiolactone or HFD and especially their combination causes a reduction of IGF-1 in serum and $\mathrm{H}_{2} \mathrm{~S}$ content in the liver of rats. Rats with NAFLD associated with HHC had levels of $\mathrm{H}_{2} \mathrm{~S}$ and IGF-1 significantly lower (respectively $22.6 \%$ and $32.2 \%$ ) than that of rats with purely NAFLD. The level of homocysteine is inversely correlated with the level of IGF-1 in blood and the level of $\mathrm{H}_{2} \mathrm{~S}$ in the liver $(r=-0.68,-0.73$, p<0.01). Formation of deficit antifibrotic mediators (IGF-1 and $\mathrm{H}_{2} \mathrm{~S}$ ) may be a factor in the progression NAFLD associated with HHC.

Conclusions. 60-day use of HFD or homocysteine thiolactone causes reduction of IGF-1 in serum and $\mathrm{H}_{2} \mathrm{~S}$ content in the liver, but the most significant shortage of mediators is as result of the combination HFD with HHC.

KEY WORDS: insulin-like growth factor-1; hydrogen sulfide; homocysteine; high fat diet; nonalcoholic fatty liver disease.

Адреса для листування: Д. О. Некрут, Вінницький національний медичний університет імені М. І. Пирогова, вул. Пирогова, 56, Вінниця, 21018, Україна, e-mail: ilchdaria@gmail.com. 